Journal of Animal and Veterinary Advances 11 (10): 1681-1687, 2012

ISSN: $1680-5593$

(C) Medwell Journals, 2012

\title{
The Immunotoxicity Studies on Jatropha curcas Kernel Meal in Young Broilers
}

\author{
Wang Dai-Gang, Ding Xue-Mei, Bai Shi-Ping, Zeng Qiu-Feng, Luo Yu-Heng and Zhang Ke-Ying \\ Key Laboratory for Animal Disease-Resistance Nutrition of China, Ministry of Education, \\ Institute of Animal Nutrition, Sichuan Agricultural University, Yaan, \\ 625014 Sichuan, P.R. China
}

\begin{abstract}
Jatropha curcas Kernel Meal (JKM) is used in animal diet as the source of vegetable protein but it is toxic to animal. The aim of this study was to evaluate the toxic effect of JKM on immune functions in young broilers. A total of $875 ; 1$ day old male Arbor Acres chickens were fed diets containing $0,3,6,9$ and $12 \% \mathrm{JKM}$ for 21 days, respectively. In the entire experimental period, the level of serum lysozyme showed no significant difference compared with control ( $\mathrm{p}>0.05$ ). Dietary JKM linearly decreased the contents of serum IgA and IgG $(\mathrm{p} \leq 0.05)$ and markedly increased the contents of serum $\operatorname{IgM}(\mathrm{p}<0.05)$ and also significantly decreased the percentage of $\mathrm{CD} 3+, \mathrm{CD} 4+$ and $\mathrm{CD} 8+$ in blood $(\mathrm{p}<0.01)$ on day 7, 14 and 21. Histopathological studies on 21 days old broilers showed that dietary JKM caused the lesions of thymus, spleen and bursa of Fabricius, exhibiting widely diffuse hemorrhages. These results suggest that dietary JKM at 3-12\% could result in immunosuppression or immunodepression in young broilers and the responses followed a dose dependent manner.
\end{abstract}

$\underline{\text { Key words: Young broilers, Jatropha curcas kernel meal, toxic, T-lymphocytes, immunoglobulin, chicken }}$

\section{INTRODUCTION}

Jatropha curcas is low-growing and drought-tolerant multipurpose small tree of significant economic importance because of its several industrial and medicinal uses (Makkar et al., 2007; Chivandi et al., 2004; Aiyelaagbe et al., 2007; Agbelusi et al., 2007). This plant grow in heavy rainfall regions also survives on barren, eroded land and under harsh climatic conditions (Becker and Makkar, 2008). Jatropha curcas seeds are rich in oil and protein. The oil is used as fuel directly or to make high quality bio-diesel by the transesterified form. In order to use the oil as biodiesel, large scale cultivations of this plant has planned or developed in India, China, Madagascar, Myanma, Philippines and many other developing countries (Francis et al., 2005). This is resulted in increasing quantity of byproducts that can be used as livestock feed.

Jatropha curcas Kernel Meal (JKM) being a byproduct that obtained after extraction of oil in J. curcas seeds is good source of protein. This meal (full defatted) contains approximately crude protein of $60 \%$ in dry matter (Makkar et al., 2008) and 90\% of which is present in the form of true protein (Makkar and Becker, 1997). The levels of all essential amino acids except lysine, in JKM protein are higher than those of FAO reference protein for a growing child of 2-5 years of age are also higher or similar compared to those of Soybean Meal (SBM) (Kumar et al., 2010a, b; Makkar and Becker, 1997). However, the seeds and kernel meal contain high levels of anti-nutritional factors such as trypsin inhibitor, lectins and phytate (Goel et al., 2007) and the toxic components phorbol esters (Makkar and Becker, 1997) which prevent their utilization as feed ingredients. Heat-labile anti-nutrients such as protease inhibitor and lectin are easy to inactivate by heating treatment whereas phorbol esters can not be destroyed by heating at temperature of $160^{\circ} \mathrm{C}$ for $30 \mathrm{~min}$ (Aderibigbe et al., 1997; Makkar and Becker, 1997; Makkar et al., 1997).

In previous studies, raw $J$. curcas seeds as well as deshelled seed meal were reported to be highly toxic to human and animal. Adam and Magzoub (1975) reported Nubian goats fed diet containing raw $J$. curcas seeds at doses ranging from $0.25-10 \mathrm{~g} / \mathrm{kg} /$ day caused poisonous with mortality occurring between 2 and 21 days (Adam and Mag zoub, 1975). The accidental consumptions of raw J. curcas seeds by children (age group of 4-8 years) showed adverse signs and symptoms such as abdominal pain, vomiting, diarrhea and burning sensation in the throat (Rai and Lakhanpal, 2008; Singh et al., 2010). Vomiting, diarrhea and acute abdominal pain began to occur gradually after $10 \mathrm{~min}$ in ingestion of seeds. Five cases of raw $J$. curcas seeds poisoning in adults were reported with same symptoms above reported (Shah and Sanmukhani, 2010). Toxic studies on raw $J$. curcas seeds in brown Hisex chicks for 4 weeks showed growing depress and widespread hemorrhage and congestion. It was also observed that there were a increase in serum

Corresponding Author: Keying Zhang, Institute of Animal Nutrition, Sichuan Agricultural University, Yaan, 625014 Sichuan, P.R. China 
glutamate oxaloacetate transaminase activities and potassium and phosphorus concentrations, a decrease in total protein and calcium concentrations (Devappa et al., 2010; El-Badwi and Adam, 1992). The diets containing $0.5 \%$ raw $J$. curcas seeds resulted in a high mortality in Brown Hisex chick (El-Badwi et al., 1995). These results indicate higher susceptibility of Hisex chicks to raw $J$. curcas seeds and chickens can be a reliable animal model to assess the toxicity of $J$. curcas or to investigate value in use for JKM (Devappa et al., 2010; Makkar and Becker, 2009).

The Immune System plays a crucial role in maintaining body health which protects the host from potentially pathogenic agents including microorganisms (viruses and bacteria), parasites and fungi to eliminate neoplastic cells and to reject foreign compounds. Consequently, this system can be the target for immunotoxic effects caused by a variety of foreign substances. The information concerning the immune system toxic effects of JKM used in animal have been scanty. Therefore, the objective of this study was to evaluate the toxic effects of JKM in diets on the immune system in young broilers.

\section{MATERIALS AND METHODS}

This study was carried out in appliance with the ethical guidelines for experimental animals by Sichuan Agricultural University (Sichuan, China).

Preparation of JKM: Jatropha curcas seeds were obtained from Huili county in Sichuan province (China). The seeds were dehulled by the small sheller and obtained seed kernels and then the kernel and shell were mixed with the kernel to shell ratio $(\mathrm{w} / \mathrm{w})$ of 10:1. The mixture was pressed in a power press to obtain JKM under following conditions, feed and press temperature of 110 and $161^{\circ} \mathrm{C}$, respectively moisture of $5 \%$. The meal was stored in cool place, determined the proximate composition and essential amino acids (Table 1) and used for the process of diets.

Diet formulation: Soybean meal, rape oil (food grade) and other feed ingredients were obtained from local market. The basal (control, JKM-free) (Table 2) was formulated according to the Nutrient Requirements of Broiler (NY/T 33-2004, China) and the diet containing $12 \% \mathrm{JKM}\left(\mathrm{JKM}_{12}\right)$ was formulated with JKM to substitute the SBM based on the same true digestible amino acid, isonitrogen and isoenergy (The ratio of true available amino acid of JKM were measured by the lab, published) and then the $\mathrm{KKM}_{12}$ diet and the control diet was mixed on the basis of the different proportion to get the other diets containing JKM
Table 1: The proximate compositions and amino acid of JKM

\begin{tabular}{lr}
\hline Items & JKM \\
\hline Proximate (\%) & \\
Moisture & 5.23 \\
Crude protein & 36.14 \\
Crude lipid & 23.50 \\
Crude ash & 8.09 \\
Phosphorus & 0.35 \\
Calcium & 0.81 \\
Gross energy $\left(\mathrm{kcal} \mathrm{g}^{-1}\right)$ & 5.19 \\
Phorbol esters $\left(\mathrm{g} \mathrm{kg}^{-1}\right)$ & 1.73 \\
Essential amino acids $\left(\mathrm{g} \mathrm{kg}^{-1}\right)$ & \\
Arginine & 40.72 \\
Histidine & 10.13 \\
Isoleucine & 16.34 \\
Leucine & 22.77 \\
Lysine & 14.08 \\
Phenylalanine & 16.01 \\
Methionine & 9.61 \\
Threonine & 13.41 \\
Valine & 13.92 \\
\hline
\end{tabular}

Table 2: Ingredients and nutrient content of experimental diets (control and

\begin{tabular}{|c|c|c|}
\hline Ingredients & Control $^{1}$ & $\mathrm{JKM}_{12}{ }^{2}$ \\
\hline Corn & 51.820 & 51.700 \\
\hline Soybean meal & 39.500 & 29.700 \\
\hline JKM & 0.000 & 12.000 \\
\hline Rapeseed oil ${ }^{3}$ & 4.200 & 2.200 \\
\hline Dicalcium phosphate & 1.800 & 1.840 \\
\hline Limestone & 1.350 & 1.160 \\
\hline L-Lysine $\mathrm{HCl}$ & 0.050 & 0.160 \\
\hline DL-Methionine & 0.200 & 0.160 \\
\hline Salt $(\mathrm{NaCl})$ & 0.400 & 0.400 \\
\hline Choline chloride (50\%) & 0.150 & 0.150 \\
\hline Vitamin premix ${ }^{3}$ & 0.030 & 0.030 \\
\hline Mineral premix ${ }^{4}$ & 0.500 & 0.050 \\
\hline Total & 100.000 & 100.000 \\
\hline \multicolumn{3}{|l|}{ Calculated nutrient content ${ }^{5}$} \\
\hline $\mathrm{ME}\left(\mathrm{kcal} \mathrm{kg}^{-1}\right)$ & $2,999.000$ & $3,002.000$ \\
\hline CP (\%) & 21.500 & 21.500 \\
\hline True digestible lysine (\%) & 1.104 & 1.103 \\
\hline True digestible methionine (\%) & 0.481 & 0.487 \\
\hline True digestible threonine (\%) & 0.733 & 0.714 \\
\hline Calcium (\%) & 1.008 & 1.007 \\
\hline Available phosphorus (\%) & 0.457 & 0.457 \\
\hline
\end{tabular}

${ }^{1}$ Control: Corn and soybean meal basal diet without any JKM; ${ }^{2} \mathrm{KJM}_{12}$ : The diet containing $12 \% \mathrm{JKM} ;{ }^{3} \mathrm{The}$ vitamin premix provided the following per kilogram of complete diet: retinyl acetate, 12,000 IU; cholecalciferol, $3,000 \mathrm{IU}$; Vitamin E, $7.5 \mathrm{mg}$; Vitamin $\mathrm{K}, 1.5 \mathrm{mg}$; thiamine, $0.6 \mathrm{mg}$; riboflavin, $4.8 \mathrm{mg}$; niacin, $10.5 \mathrm{mg}$; pantothenic acid, $7.5 \mathrm{mg}$; pyridoxine, $1.8 \mathrm{mg}$; biotin, $0.135 \mathrm{mg}$; folic acid, $0.15 \mathrm{mg}$ and Vitamin $\mathrm{B}_{12}, 0.01 \mathrm{mg}$; ${ }^{4}$ The mineral premix provided the following per kilogram of complete diet: $\mathrm{Cu}\left(\mathrm{CuSO}_{4}-5 \mathrm{H}_{2} \mathrm{O}\right) 8 \mathrm{mg}, \mathrm{Mn}\left(\mathrm{MnSO}_{4} \cdot \mathrm{H}_{2} \mathrm{O}\right) 120 \mathrm{mg}, \mathrm{Zn}\left(\mathrm{ZnSO}_{4} \cdot 6 \mathrm{H}_{2} \mathrm{O}\right)$ $100 \mathrm{mg}, \mathrm{Fe}\left(\mathrm{FeSO}_{4} \cdot 6 \mathrm{H}_{2} \mathrm{O}\right) 100 \mathrm{mg}, \mathrm{I}(\mathrm{KI}) 0.70 \mathrm{mg}$, Se $\left(\mathrm{Na}_{2} \mathrm{SeO}_{3}\right) 0.30 \mathrm{mg}$; SNutrient contents were calculated values according to China Feed Database Information Web Centre in 2009

of 3 (Control: $\mathrm{JKM}_{12}=3: 1, \mathrm{JKM}_{3}$ ), 6 (Control: $\mathrm{JKM}_{12}=1: 1$, $\left.\mathrm{JKM}_{6}\right)$ and $9 \%$ (Control: $\mathrm{JKM}_{12}=1: 3, \mathrm{KM}_{9}$ ), respectively. All diets were fed in mash form.

Birds, management and experimental design: A total of 875, 1 day old male Arbor Acres chickens with an initial BW of $41.27 \pm 0.11$ obtained from commercial hatchery were used in the study. The experiment was conducted as a 
completely randomly experimental design. The chickens were randomly divided into five groups by $\mathrm{BW}$ with seven replicates of twenty five chickens in a metal battery cage $(1 \times 2 \mathrm{~m})$. The 1 group designated as the Control $(\mathrm{C})$ group was fed with the basal diet (control, JKM-free) and other four groups was fed with the diets containing JKM levels of $3,6,9$ and $12 \%$, respectively. Room temperature was maintained at $35^{\circ} \mathrm{C}$ during the 1 st 3 days of life and then was decreased gradually according to age until attaining $24^{\circ} \mathrm{C}$ at 21 days. Artificial lighting was continuous. Chickens were free access to feed and water throughout trial. Mortality, except sampled chickens was recorded during the experiment. Three birds of average BW per each replicate on day 7 th and 2nd birds of average BW per each replicate on day 14 th and 21 st were sampled blood from jugular vein after a $12 \mathrm{~h}$ overnight fast and then killed by exsanguinations. Peripheral blood from one bird was transferred into an EDTA-coated tube. Blood of the other was centrifuged at $1500 \mathrm{~g}$ for $5 \mathrm{~min}$ to obtain serum at room temperature which was stored at $-20^{\circ} \mathrm{C}$ for further analysis. At 21 days of age, the spleen, thymus and bursa of fabricus in broiler were removed and fixed in $4 \%$ of paraformaldehyde solution for histopathological studies.

Proximate analysis: Samples of JKM were analyzed for dry matter, ash, crude protein and lipid by the standard methods of the Association of Official Analytical Chemists (AOAC, 2000). Gross energy of JKM was determined with bomb calorimeter. The content of phorbol esters was measured using HPLC according to the method of Rakshit et al. (2008).

Amino acid analysis: The amino acid compositions of JKM were determined using HPLC after hydrolyzing the samples with $6 \mathrm{M} \mathrm{Hcl}$ for $24 \mathrm{~h}$ at $110^{\circ} \mathrm{C}$. The sulphur-containing amino acids were oxidised with performic acid before the acid hydrolysis. But tryptophane was not analyzed.

Blood analysis: Serum $\operatorname{IgA}, \operatorname{IgG}$ and $\operatorname{IgM}$ serum were measured by double-antibody sandwich ELISA using commercial kit ( $\mathrm{R}$ and $\mathrm{D}$ Systems). Serum lysozyme activity (LZM, A050) was measured spectrophotometrically with commercial diagnosed kit (Jiancheng Bioengineering Institute, Nanjing, China). The peripheral blood of seven birds in each group was taken to determine the percentages of CD3+, CD4+ and CD8+ Tcells by the flow cytometry at 7,14 and 21 days of age. FCM Method Anti-clotting peripheral blood (1 mL) was put in a test tube containing $1 \mathrm{~mL} 0.1 \mathrm{~mol} \mathrm{~L}^{-1}(\mathrm{pH} 7.4)$ Phosphate-Buffered Saline (PBS) and then transferred to centrifuge tube containing $2 \mathrm{~mL}$ lymphocyte separation medium and centrifuged at $200 \mathrm{~g} \mathrm{~min}^{-1}$ for $20 \mathrm{~min}$. Approximately, $0.5 \mathrm{~mL}$ lymphocyte layer was collected, transferred to another centrifuge tube and then $2 \mathrm{~mL}$ PBS added and centrifuged at $200 \mathrm{~g} \mathrm{~min}^{-1}$ for $5 \mathrm{~min}$. The supernatant was discarded. The cell concentration was determined using the normal counting method of blood cells and then diluted to $1.0 \times 10^{6}$ cells $\mathrm{mL}^{-1}$ with PBS. Lymphocytes were adjusted to a concentration of $1.0 \times 10^{6}$ cells $\mathrm{mL}^{-1}$ with PBS. The aforementioned $1 \mathrm{~mL}$ cell suspension was transferred to another centrifuge tube and centrifuged at $200 \mathrm{~g} \mathrm{~min}^{-1}$ for $5 \mathrm{~min}$. The supernatant was discarded. The cells were respectively stained with $10 \mu \mathrm{L}$ mouse anti-chicken CD3-FITC (clone CT-3, Southern Biotech), mouse anti-chicken CD4-FITC (clone CT4, Southern Biotech) and mouse anti-chicken CD8aRPE (clone CT-8, Southern Biotech) for 15-20 min at room temperature and then $2 \mathrm{~mL}$ PBS added and centrifugal. The supernatant was discarded. The cells were resuspended in $0.5 \mathrm{~mL}$ PBS and examined by fluorescence activated cell sorter (FACS, Coulter Corp., USA).

Histopathological studies: The fixed tissues were dehydrated and embedded in paraffin and serial sections were prepared then stained with haematoxylin and eosin for histopathological study.

Statistical analysis: All data were subjected to a one-way Analysis of Variance (ANOVA) according to the GLM procedure of SAS (Version 9.2e, Institute Inc., Cary, NC). The significance of difference between means was tested by Duncan's multiple range test $(\mathrm{p}<0.05)$. The effect of supplemental levels of JKM was determined using orthogonal polynomials for linear and quadratic effects.

\section{RESULTS AND DISCUSSION}

Mortality of chicks at the whole experimental period: As shown in Table 3 , the death of chicks occurred in a dose dependent manner. The higher the addition level of JKM, the sooner the chicks died and no birds was survival in $\mathrm{JKM}_{9}$ and $\mathrm{JKM}_{12}$ before the $3 \mathrm{rd}$ week. But some birds fed diets of $\mathrm{JKM}_{3}$ and $\mathrm{JKM}_{6}$ were survived.

Lysozyme activity: The serum lysozyme contents in different experimental groups are shown in Table 4. No significant difference in lysozyme activity were observed in the entire experimental period $(\mathrm{p}>0.05)$.

Table 3: Mortality rate of broiler chicks at per week of the whole experimental period

\begin{tabular}{|c|c|c|c|c|c|}
\hline \multirow[b]{2}{*}{ Mortality weeks $(\%)$} & \multicolumn{5}{|c|}{ JKM level in diets (\%) } \\
\hline & 0 & 3 & 6 & $9^{1}$ & $12^{1}$ \\
\hline 1 st & 0 & 1.70 & 7.43 & 35.43 & 56.00 \\
\hline 2 nd & 0 & 10.29 & 43.43 & 44.57 & 27.43 \\
\hline$\underline{3 \mathrm{rd}}$ & 0 & 6.29 & 12.00 & - & - \\
\hline
\end{tabular}

${ }^{1}$ All broiler chicks in $\mathrm{JKM}_{9}$ and $\mathrm{JKM}_{12}$ treatment groups except for selected chicks to be sampled, died before the 3rd week 
Serum immunoglobulin A, G, and M contents: Serum immunoglobulin contents of broilers were affected by dietary JKM level (Table 5). Compared with control with the increase of dietary JKM level, the contents of serum $\operatorname{Ig} \mathrm{A}$ and IgG linearly reduced in throughout experiment $(\mathrm{p} \leq 0.05)$, moreover, IgA contents quadratically decreased on day 14 th and 21 st $(\mathrm{p}<0.05)$ and serum IgG contents also quadratically decreased on day 7 th and 14 th $(\mathrm{p}<0.01)$. In entire experimental period, the concentration of serum $\operatorname{IgM}$ linearly and quadratically increased when birds were fed diets containing different level of $\mathrm{KKM}(\mathrm{p}<0.05)$.

Peripheral blood T-lymphocyte subpopulations: Dietary JKM level had a dose response effect on peripheral blood T-lymphocytes subsets in broilers (Table 6). When dietary JKM increased, the percentage of $\mathrm{CD} 3+, \mathrm{CD} 4+$ and CD8+ T-lymphocytes decreased linearly and quadratically on day 7 th, 14 th and 21 st $(\mathrm{p}<0.01)$.

Histopathology studies: Histopathological studies of the organs showed different experimental diets produced pathological changes in thymus, spleen and bursa of Fabricius in broiler chickens. Severely pathological changes, widely hemorrhages and exudates in thymus were observed in all of JKM treatment groups (Fig. 1), the similar clinical signs were also seen in spleen (Fig. 2) but the hemorrhage and hyperemia in bursa of Fabricius were

Table 4: Effects of dietary JKM level on serum lysozyme contents in broiler chickens

\begin{tabular}{|c|c|c|c|c|c|c|}
\hline \multirow[b]{2}{*}{$\begin{array}{l}\text { Lysozyme contents } \\
\left(\mu \mathrm{g} \mathrm{mL}^{-1}\right)(\text { days })\end{array}$} & \multicolumn{5}{|c|}{ JKM level in diets (\%) } & \multirow[b]{2}{*}{ SEM } \\
\hline & 0 & 3 & 6 & 9 & 12 & \\
\hline 7 & 1. $31^{a b}$ & $1.25^{\mathrm{ab}}$ & $1.49^{\mathrm{a}}$ & $1.16^{b}$ & $1.33^{\mathrm{ab}}$ & 0.04 \\
\hline 14 & $1.30^{\mathrm{a}}$ & $1.38^{\mathrm{a}}$ & $1.43^{\mathrm{a}}$ & $1.30^{\mathrm{a}}$ & $1.37^{\mathrm{a}}$ & 0.02 \\
\hline 21 & $1.42^{\mathrm{a}}$ & $1.51^{\mathrm{a}}$ & $1.54^{\mathrm{a}}$ & - & - & 0.03 \\
\hline
\end{tabular}

Values are Means $(n=7)$. Means value in the same row with different superscript differ significantly $(\mathrm{p}<0.05)$ only found in the chicks fed 6\% JKM (Fig. 3). The thymus, spleen and bursa of Fabricius in the control

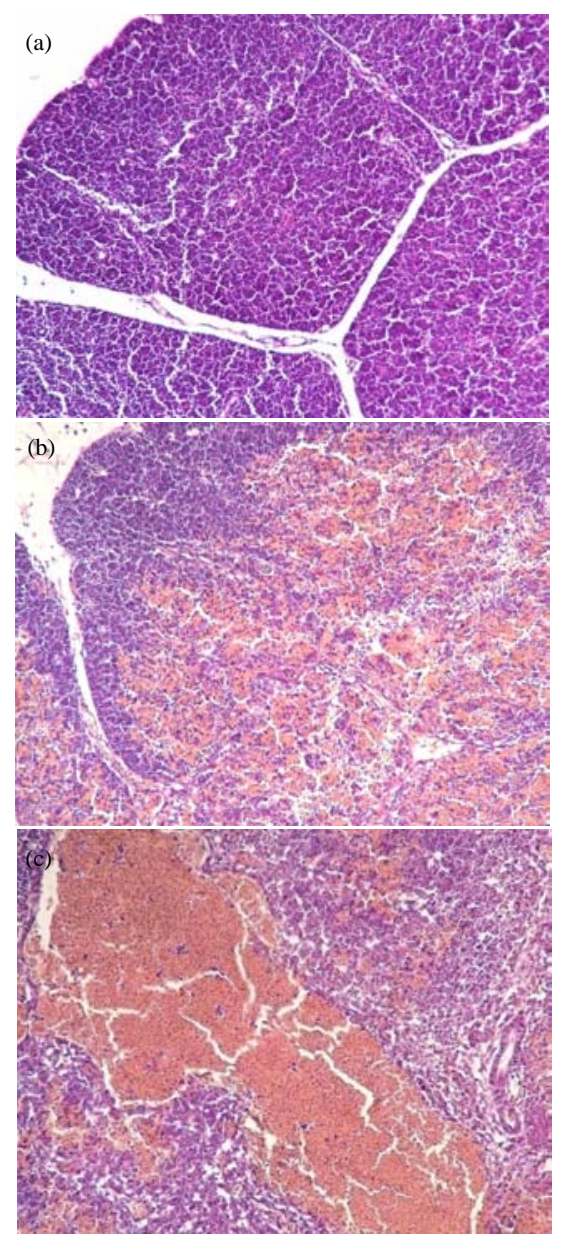

Fig. 1: Pathological change of thymus observed in; a) Control (Normal); b) $\mathrm{JKM}_{3}$ and c) $\mathrm{JKM}_{6}$ treatments. $\mathrm{b}$ and $\mathrm{c}$ widely and severely hemorrhages. $\mathrm{H}$ and $\mathrm{E} \times 200$

Table 5: Effects of dietary JKM level on serum immunoglobulin A, G and M contents in broiler chickens

\begin{tabular}{|c|c|c|c|c|c|c|c|c|}
\hline \multirow[b]{2}{*}{ Items (days) } & \multicolumn{5}{|c|}{ JKM level in diets $(\%)$} & \multirow[b]{2}{*}{ SEM } & \multicolumn{2}{|c|}{$\mathrm{p}$-value $\mathrm{e}^{\mathrm{l}}$} \\
\hline & 0 & 3 & 6 & 9 & 12 & & $\mathrm{~L}$ & $\mathrm{Q}$ \\
\hline \multicolumn{9}{|c|}{$\operatorname{IgA}\left(\mu \mathrm{g} \mathrm{mL}^{-1}\right)$} \\
\hline 7 & $10.29^{\mathrm{ab}}$ & $12.60^{\mathrm{a}}$ & $9.62^{\mathrm{ab}}$ & $9.42^{\mathrm{ab}}$ & $8.05^{b}$ & 0.52 & 0.04 & 0.61 \\
\hline 14 & $11.04^{\mathrm{ab}}$ & $12.46^{\mathrm{a}}$ & $10.58^{\mathrm{ab}}$ & $9.28^{b}$ & $9.12^{\mathrm{b}}$ & 0.40 & $<0.01$ & 0.02 \\
\hline 21 & $11.64^{\mathrm{a}}$ & $12.28^{\mathrm{a}}$ & $10.20^{b}$ & - & - & 0.31 & 0.05 & $<0.01$ \\
\hline \multicolumn{9}{|c|}{$\operatorname{IgG}\left(\mathbf{n g ~ m L} \mathbf{~}^{-1}\right)$} \\
\hline 7 & $673.65^{\mathrm{a}}$ & $618.50^{\mathrm{ab}}$ & $556.55^{b}$ & $552.65^{b}$ & $530.55^{b}$ & 16.89 & $<0.01$ & $<0.01$ \\
\hline 14 & $619.28^{a}$ & $568.21^{\mathrm{a}}$ & $444.81^{b}$ & $465.70^{b}$ & $471.83^{b}$ & 17.05 & $<0.01$ & $<0.01$ \\
\hline 21 & $529.87^{\mathrm{a}}$ & $459.59^{a b}$ & $452.23^{b}$ & - & - & 15.68 & 0.04 & 0.07 \\
\hline \multicolumn{9}{|c|}{$\operatorname{IgM}\left(\mathrm{ng} \mathrm{mL}^{-1}\right)$} \\
\hline 7 & $235.14^{\mathrm{a}}$ & $275.46^{\mathrm{ab}}$ & $292.34^{b}$ & $285.17^{\circ}$ & $292.31^{b}$ & 7.31 & 0.01 & 0.01 \\
\hline 14 & $249.74^{\mathrm{a}}$ & $278.35^{\mathrm{ab}}$ & $309.12^{b}$ & $290.82^{b}$ & $310.36^{b}$ & 6.51 & $<0.01$ & $<0.01$ \\
\hline$\underline{21}$ & $218.47^{\mathrm{a}}$ & $266.37^{b}$ & $259.97^{\mathrm{b}}$ & - & - & 8.33 & 0.04 & 0.03 \\
\hline
\end{tabular}


Table 6: Effect of dietary JKM level on blood T-lymphocyte subpopulations in broiler chickens

\begin{tabular}{|c|c|c|c|c|c|c|c|c|}
\hline \multirow[b]{2}{*}{ Item (days) } & \multicolumn{5}{|c|}{ JKM level in diets (\%) } & \multirow[b]{2}{*}{ SEM } & \multicolumn{2}{|c|}{ p-value ${ }^{1}$} \\
\hline & 0 & 3 & 6 & 9 & 12 & & $\mathrm{~L}$ & Q \\
\hline \multicolumn{9}{|l|}{ CD3+(\%) } \\
\hline 7 & $10.83^{\mathrm{a}}$ & $5.26^{b}$ & $3.03^{\mathrm{c}}$ & $3.51^{\mathrm{c}}$ & $2.05^{\mathrm{C}}$ & 0.57 & $<0.01$ & $<0.01$ \\
\hline 14 & $17.77^{\mathrm{a}}$ & $12.26^{6}$ & $6.70^{\circ}$ & $5.45^{\circ}$ & $2.98^{\mathrm{c}}$ & 0.12 & $<0.01$ & $<0.01$ \\
\hline 21 & $22.72^{\mathrm{a}}$ & $9.10^{b}$ & $5.10^{\circ}$ & - & - & 1.75 & $<0.01$ & $<0.01$ \\
\hline \multicolumn{9}{|l|}{$\mathrm{CD} 4+(\%)$} \\
\hline 7 & $7.50^{\mathrm{a}}$ & $4.92^{b}$ & $3.23^{\text {bc }}$ & $3.57^{\mathrm{bc}}$ & $1.88^{c}$ & 0.40 & $<0.01$ & $<0.01$ \\
\hline 14 & $12.42^{\mathrm{a}}$ & $8.11^{b}$ & $6.72^{\mathrm{bc}}$ & $5.56^{\mathrm{bc}}$ & $3.25^{\mathrm{c}}$ & 0.72 & $<0.01$ & $<0.01$ \\
\hline 21 & $19.06^{\mathrm{a}}$ & $8.94^{b}$ & $5.44^{\mathrm{b}}$ & - & - & 1.47 & $<0.01$ & $<0.01$ \\
\hline \multicolumn{9}{|l|}{$\mathrm{CD} 8+(\%)$} \\
\hline 7 & $8.42^{\mathrm{a}}$ & $2.84^{b}$ & $3.67^{\mathrm{b}}$ & $4.68^{b}$ & $2.32^{b}$ & 0.60 & $<0.01$ & $<0.01$ \\
\hline 14 & $9.26^{\mathrm{a}}$ & $2.70^{b}$ & $3.27^{b}$ & $2.32^{b}$ & $2.99^{b}$ & 0.67 & $<0.01$ & $<0.01$ \\
\hline 21 & $10.67^{\mathrm{a}}$ & $3.78^{b}$ & $3.20^{b}$ & - & - & 0.86 & $<0.01$ & $<0.01$ \\
\hline
\end{tabular}

Values are means $(n=5)$, means value in the same row with different superscript differ significantly $(\mathrm{p}<0.05),{ }^{1}$ Orthogonal contrasts: $\mathrm{L}=$ Linear and $Q=$ Quadratic effect of supplemental JKM

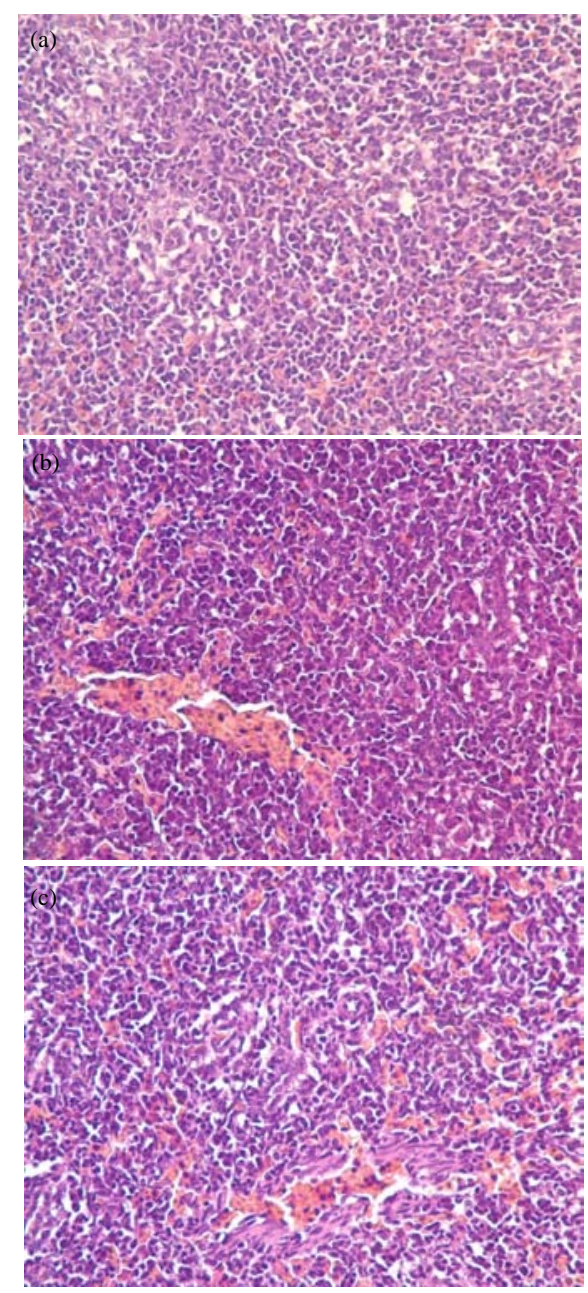

Fig. 2: Pathological change of spleen observed in; a) Control (Normal); b) $\mathrm{JKM}_{3}$ and c) $\mathrm{JKM}_{6}$ treatments. $\mathrm{b}$ and $\mathrm{c}$ widely hemorrhages. $\mathrm{H}$ and $\mathrm{E}$ $\mathrm{x} 400$ group didn't show any of pathological changes. In the present study, all diets containing 3-12\% JKM caused broilers mortality. The higher the JKM level was in the diet, the faster the animal died. These results indicate JKM obtained by pressing at temperature of $161^{\circ} \mathrm{C}$ are highly toxic to broilers. Rakshit et al. (2008) reported whether treated or untreated using chemical and heating, all groups occurred in mortality of rats. The rats fed with the treated meal exhibited delayed mortality compared to untreated meal fed rats (Rakshit et al., 2008). The major toxicity in $J$. curcas seeds are indentified as the phorbol esters (Makkar et al., 1998; Makkar and Becker, 1997) which can not be completely removed from $J$. curcas seeds or kernel meal by chemical and mechanical methods (Aregheore et al., 2003; Kumar et al., 2010a; Rakshit et al., 2008).
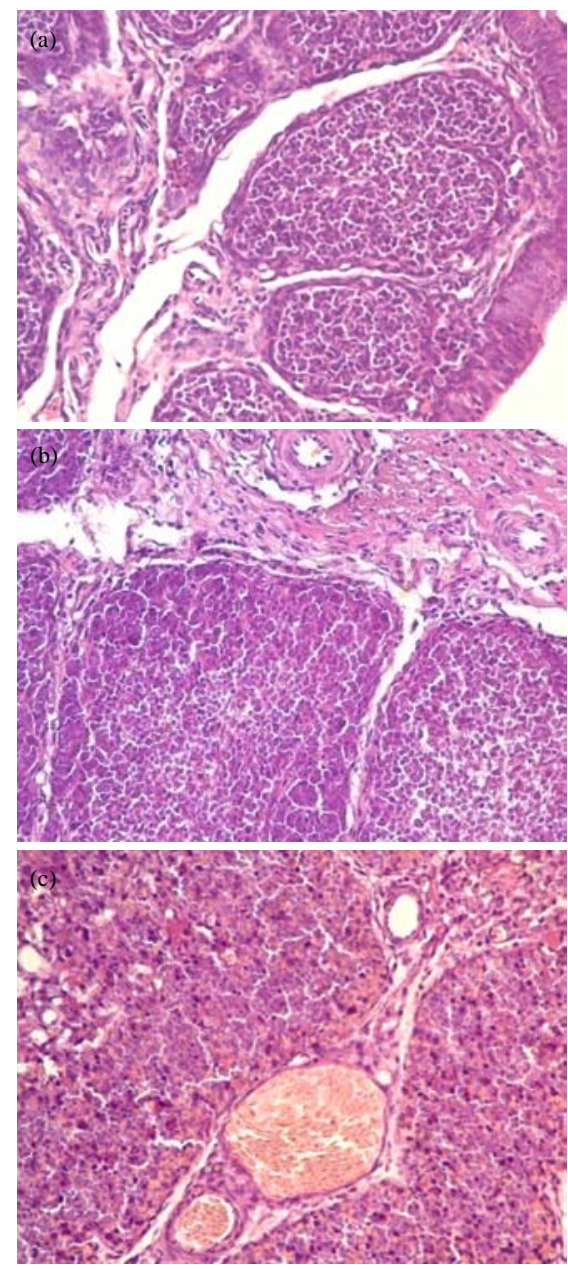

Fig. 3: Pathological changes of bursa of Fabricius observed; a) Control; b) $\mathrm{JKM}_{3}$ Normal bursa of Fabricius and c) $\mathrm{JKM}_{6}$ widely diffuse hemorrhages and hyperemic vein. $\mathrm{H}$ and $\mathrm{E} \times 400$ 
The phorbol esters content depends on the residual oil present in the cake or the meal after processing (Rakshit et al., 2008). The immune system plays a central role in guarding health against foreign substances and protects from invasion of potential pathological agents. It is composed of two major subdivisions, the innate or nonspecific immune system and acquired or specific Immune System. In this study, dietary JKM did not affect the lysozyme activity in serum which is mainly secreted by phagocytes and is a nonspecific immune indicator. The bursa of Fabricius in birds which is equivalent to bone marrow in mammals is the primary organs of lymphopoiesis and plays pivotal for the normal development of B-lymphocytes (Glick, 1991; Glick et al., 1956; Pavelka and Roth, 2005; Ratcliffe, 2006). Blymphocytes represent the major cells of the antibodymediated humoral immunity.

In this study, dietary JKM supplementation by in large, decreased the contents of serum immunoglobulin, suggesting that the toxin in JKM may suppress the responses of the humoral immune system and the immuosupression or immunodepression may be a result of the direct histological damage to the bursa of Fabricius. The alteration and histological lesion in bursa of Fabricius which resulted in immunosuppression or immunodepression were also observed in birds (Ezeokoli et al., 1990; Qureshi and Edens, 1997). The percentage of CD3+, CD4+ and CD8+ T-lymphocytes can be used to assess the immune status of birds owing to their importance role in cell immunity (Arstila et al., 1994; Erf, 2004; Lillehoj and Trout, 1994).

In the present study, the proportions of CD3+, CD4+ and CD8+ T-lymphocytes in broilers were decreased linearly and quadratically when the dietary JKM supplemental levels increased indicating that the effect of dietary JKM on subpopulations of peripheral blood T-lymphocytes exhibits a dose suppressive response to cell immunity of birds which may be caused by the toxin in JKM directly damaging to thymus (Fig. 1).

\section{CONCLUSION}

The data obtained in the present study exhibited that dietary JKM caused the serious histological damage to immune organs and decreased the counts of the serum immunoglobulin and blood T-lymphocytes. The effect of dietary JKM on the immune functions including humoral immunity and cell immunity was a dose suppressive manner.

\section{ACKNOWLEDGEMENTS}

This study was supported by the international scientific corporation project of the Ministry of Science and Technology of China (2007DFA30920) and the specific research supporting program for academic sustentation research team in Sichuan Agricultural University.

\section{REFERENCES}

AOAC, 2000. Official Methods of Analysis. 17th Edn., Association of Official Analytical Chemists, Washington, DC.

Adam, S.E. and M. Magzoub, 1975. Toxicity of Jatropha cucurcas for goats. Toxicology, 4: 347-354.

Aderibigbe, A.O., H.P.S. Makkar, K. Becker and N.N. Foidl, 1997. Chemical composition and effect of heat on organic matter and nitrogen degradability and some anti nutritional components of Jatropha meal. Anim. Feed Sci. Technol., 67: 223-243.

Agbelusi, G.A., O.A. Odukoya and A.F. Otegbeye, 2007. In vitro screening of chewing stick extracts and sap on oral pathogens: Immune compromised infections. Biotechnology, 6: 97-100.

Aiyelaagbe, O.O., B.A. Adeniyi, O.F. Fatunsin and B.D. Arimah, 2007. In vitro antimicrobial activity and phytochemical analysis of Jatropha curcas roots. Int. J. Pharmacol., 3: 106-110.

Aregheore, E.M., K. Becker and H.P.S. Makkar, 2003. Detoxification of a toxic variety of Jatropha curcas using heat and chemical treatments, and preliminary nutritional evaluation with rats. South Pacific J. Nat. Sci., 21: 50-56.

Arstila, T., O. Vainio and O. Lassila, 1994. Central role of CD4+ T cells in avian immune response. Poult. Sci., 73: 1019-1026.

Becker, K. and H.P.S. Makkar, 2008. Jatropha curcas: A potential source for tomorrow's oil and biodiesel. Lipid Technol., 20: 104-107.

Chivandi, E., J.P. Mtimuni, J.S. Read and S.M. Makuza, 2004. Effect of processing method on phorbol esters concentration, total phenolics, trypsin inhibitor activity and the proximate composition of the zimbabwean jatropha curcas provenance: A potential livestock feed. Pak. J. Biol. Sci., 7: 1001-1005.

Devappa, R.K., H.P. Makkar and K. Becker, 2010. Jatropha toxicity-a review. J. Toxicol. Environ. Health B Crit. Rev., 13: 476-507.

El-Badwi, S.M. and S.E. Adam, 1992. Toxic effects of low levels of dietary Jatropha curcas seed on brown hisex chicks. Vet. Hum. Toxicol., 34: 112-115. 
El-Badwi, S.M., S.E. Adam and H.J. Hapke, 1995. Comparative toxicity of Ricinus communis and Jatropha curcas in Brown Hisex chicks. Dtsch. Tierarztl. Wochenschr., 102: 75-77.

Erf, G.F., 2004. Cell-mediated immunity in poultry. Poult. Sci., 83: 580-590.

Ezeokoli, C., E. Ityondo, A. Nwannenna and J. Umoh, 1990. Immunosuppression and histopathological changes in the bursa of Fabricius associated with infectious bursal disease vaccination in chicken. Comp. Immunol. Microbiol. Infectious Dis., 13: $181-188$.

Francis, G., R. Edinger and K. Becker, 2005. A Concept for Simultaneous Wasteland Reclamation, Fuel Production and Socio-economic Development in Degraded Areas in India: Need, Potential and Perspectives of Jatropha Plantations. Royaume University, Blackwell, Oxford, pp: 13.

Glick, B., 1991. Historical perspective: The bursa of Fabricius and its influence on B-cell development, past and present. Vet. Immunol. Immunopathol., 30: 3-12.

Glick, B., T.S. Chang and R.G. Jaap, 1956. The bursa of fabricius and antibody production. Poult. Sci., 35: 224-225.

Goel, G., H.P.S. Makkar, G. Francis and K. Becker, 2007. Phorbol esters: Structure, biological activity and toxicity in animals. Int. J. Toxicol., 26: 279-288.

Kumar, V., H.P. Makkar, W. Amselgruber and K. Becker, 2010b. Physiological, haematological and histopathological responses in common carp (Cyprinus carpio L.) fingerlings fed with differently detoxified Jatropha curcas kernel meal. Food Chem. Toxicol., 48: 2063-2072.

Kumar, V., H.P.S Makkar, G. Francis and K. Becker, 2010a. Dietary inclusion of detoxified Jatropha curcas kernel meal: effects on growth performance and metabolic efficiency in common carp, Cyprinus carpio L. Fish Physiol. Biochem., 36: 1159-1170.

Lillehoj, H. and J. Trout, 1994. CD8+ T cell-coccidia interactions. Parasitol. Today, 10: 10-14.

Makkar, H.P., K. Becker and J. Liu, 2008. Role of Jatropha curcas in sustainable land management and towards energy and food security-a joint BMBF-MOST effort. Proceedings of ERSEC International Conference on Sustainable Land Use and Water Management, October 8-10, 2008, Beijing, China.
Makkar, H.P.S. and K. Becker, 1997. Potential of Jatropha curcas Seed Meal as a Protein Supplement to Livestock Feed, Constraints to its Utilization and Possible Strategies to Overcome Constraints. Nicaragua Publishers, Managua.

Makkar, H.P.S. and K. Becker, 2009. Jatropha curcas, a promising crop for the generation of biodiesel and value-added coproducts. Eur. J. Lipid Sci. Technol., 111: 773-787.

Makkar, H.P.S., A.O. Aderibigbe and K. Becker, 1998. Comparative evaluation of non-toxic and toxic varieties of Jatropha curcas for chemical composition, digestibility, protein degradability and toxic factors. Food Chem., 62: 207-215.

Makkar, H.P.S., G. Francis and K. Becker, 2007. Bioactivity of phytochemicals in some lesser-known plants and their effects and potential applications in livestock and aquaculture production systems. Animal, 1: 1371-1391.

Makkar, H.P.S., K. Becker, F. Sporer and M. Wink, 1997. Studies on nutritive potential and toxic constituents of different provenances of Jatropha curcas. J. Agric. Food Chem., 45: 3152-3157.

Pavelka, M. and J. Roth, 2005. Functional Ultrastructure: Atlas of Tissue Biology and Pathology. Springer, New York, Pages: 342.

Qureshi, M.A. and F.W. Edens, 1997. Immune system dysfunction during exposure to poult enteritis and mortality syndrom agent. Poult. Sci., 76: 564-569.

Rai, D. and P. Lakhanpal, 2008. Jatropha curcas poisoning in pediatric patients, Mauritius. Int. J. Pediatrics Neonatol., Vol. 8

Rakshit, K.D., J. Darukeshwara, K.R. Raj, K. Narasimhamurthy, P. Saibaba and S. Bhagya, 2008. Toxicity studies of detoxified Jatropha meal (Jatropha curcas) in rats. Food Chem. Toxicol., 46: 3621-3625.

Ratcliffe, M.J.H., 2006. Antibodies, immunoglobulin genes and the bursa of Fabricius in chicken B cell development. Dev. Comp. Immunol., 30: 101-118.

Shah, V. and J. Sanmukhani, 2010. A study of five cases of Jatropha curcas poisoning. J. Assoc. Phys. India, 58: 245-246.

Singh, R., D. Singh and A. Mahendrakar, 2010. Jatropha poisoning in children. Med. J. Armed Forces India, 66: $80-81$. 